Canadian Art Review

\title{
From Flatness to Space and Back Again: Concepts of Representation in the Work of Gerhard Richter and Sigmar Polke
}

\author{
Julia Gelshorn
}

Volume 31, numéro 1-2, 2006

URI : https://id.erudit.org/iderudit/1069621ar

DOI : https://doi.org/10.7202/1069621ar

\section{Aller au sommaire du numéro}

\section{Éditeur(s)}

UAAC-AAUC (University Art Association of Canada | Association d'art des universités du Canada)

\section{ISSN}

0315-9906 (imprimé)

1918-4778 (numérique)

Découvrir la revue

Citer cet article

Gelshorn, J. (2006). From Flatness to Space and Back Again: Concepts of Representation in the Work of Gerhard Richter and Sigmar Polke. RACAR : Revue d'art canadienne / Canadian Art Review, 31(1-2), $28-41$.

https://doi.org/10.7202/1069621ar

\section{Résumé de l'article}

Quand Sigmar Polke et Gerhard Richter entament leurs carrières dans les années 1960, l'histoire de l'art est encore régie par l'idée d'un progrès allant de l'art figuratif à l'art abstrait. Dans ce contexte, la représentation de l'espace par des dispositifs traditionnels n'est plus le sujet de l'art, puisque les peintres modernes ont réfléchi à la planéité de l'image en réduisant la peinture à ses éléments de base, soit la couleur et la forme. Les tableaux de Richter et Polke contredisent cette notion de progrès linéaire. Ils nient la dialectique de la "figuration " et de l'« abstraction ", surtout les concepts compétitifs de " planéité » et d'« espace fictif ». Leur révision des différents styles, genres et éléments picturaux peut se comprendre comme une réflexion sur les implications sociales et politiques des concepts stylistiques, de même que sur le fardeau idéologique des formes représentationnelles. Un examen d'images exemplaires des modes de représentation privilégiées dans leurs oeuvres - les célèbres fenêtres, rideaux et peintures transparentes de même que d'autres dispositifs moins explicites - révèle que les deux artistes ont opté pour une position intermédiaire qui triomphe de la polarisation entre l'image comme fenêtre et l'image comme surface plane.
Tous droits réservés @ UAAC-AAUC (University Art Association of Canada | Association d'art des universités du Canada), 2006
Ce document est protégé par la loi sur le droit d'auteur. L’utilisation des services d'Érudit (y compris la reproduction) est assujettie à sa politique d'utilisation que vous pouvez consulter en ligne.

https://apropos.erudit.org/fr/usagers/politique-dutilisation/ 


\title{
From Flatness to Space and Back Again: Concepts of Repre- sentation in the Work of Gerhard Richter and Sigmar Polke
}

\author{
Julla GeLshorn, University of ZuRICH, SWITZERLAND
}

\begin{abstract}
Résumé
Quand Sigmar Polke et Gerhard Richter entament leurs carrières dans les années 1960, l'histoire de l'art est encore régie par l'idée d'un progrès allant de l'art figuratif à l'art abstrait. Dans ce contexte. la représentation de l'espace par des dispositifs traditionnels n'est plus le sujet de l'art, puisque les peintres modernes ont réfléchi à la planéité de l'image en réduisant la peinture à ses éléments de base, soit la couleur et la forme. Les tableaux de Richter et Polke contredisent cette notion de progrès linéaire. Ils nient la dialectique de la « figuration » et de l'« abstraction », surtout les concepts compétitifs de «planéité » et d'« despace fictif». Leur révision des différents
\end{abstract}

styles, genres et éléments picturaux peut se comprendre comme une réflexion sur les implications sociales et politiques des concepts stylistiques, de même que sur le fardeau idéologique des formes représentationnelles. Un examen d'images exemplaires des modes de représentation privilégiées dans leurs œuvres - les célèbres fenê. tres, rideaux et peintures transparentes de même que d'autres dispositifs moins explicites - révèle que les deux artistes ont opté pour une position intermédiaire qui triomphe de la polarisation entre l'image comme fenêtre et l'image comme surface plane.
$T_{\mathrm{w}}$ wo photographs (figs. 1, 2) of Gerhard Richtcr and Sigmar Polke with their respective works can be read as performative demonstrations of how these artists deal with traditional concepts of representation. In Polke's photograph, we cannot speak of the artist as standing in front of his work Blue Flowers of 1992 , since he is in fact hanging on its frame while demonstrating that the mysterious blue spot is actually painted on a physical support. Evidently this support is strong enough to bear the artist's weight. Moreover, its translucent surface not only displays the expansion of the blue colour, it also reveals the artist's leg behind it.

In the photograph of Gerhard Richter, taken in 1966 in his studio in Düsseldorf, the artist is standing in front of his work Curtain. Unlikc Polke's photo, we do not immediately realize that Richter stands in front of a picture. The proportions of the painted curtain and of the artist's height make us believe that he is standing in front of a real curtain. Only at a second glance do we notice the easel behind the canvas and realize that Richter poses in front of an illusory curtain, painted to deceive our eyes in the same way Parrhasios deceived Zeuxis.'

The two photographs are examples of the ambivalence with which both artists treat the opposing representational concepts of illusory space and flat surface. Their paintings clearly allude to the Albertian concept of the image as an open window through which we see the subject. ${ }^{2}$ However, the photographic reproductions of both canvases emphasize that they are essentially flat objects. Furthermore, the photos reveal the different attitudes adopted by the two artists in their exploration of traditional paradigms associated with visual perception. While Polke presents himself as a sort of clown making fun of the mysterious appearance of his own work, Richter appears serious and thoughtful. These attitudes also find expression in their works. Whereas Polke often confronts us with ironic provocations, Richter offers serious reproductions of traditional models.
Richter and Polke mer in 1962 at the Düsseldorf Academy of Art, where they became friends as well as competitors. ${ }^{3}$ While Polke had alrcady moved from East to West Germany as a teenager, Richter had left the German Democratic Republic only a year before. Having been drilled by the doctrine of Socialist Realism in the East, Richter's abrupt move to the West confronted him with a completely antagonistic mode of thought. Although everything seemed possible in this Western art world, Richter soon realized that, in West Germany, abstraction had developed into an ideology that was as prevalent as its realist counterpart in the East. ${ }^{4}$ The Kassel Documenta II in 1959 inspired Richter's move to West Germany by presenting an unknown variety of artistic liberties and styles. However, at the same time, it propagated abstraction as the only "universal" language of art. As indicated by the catalogue of Documenta II and Clement Greenberg's writings of the same time, art history was still under the impact of the idea of progress leading from figurative art towards abstract art. ${ }^{5}$ Since the early twentieth century, but especially after the Second World War, abstract art had been the paradigm of progress, universality, and freedom. ${ }^{6}$ In this context, traditional pictorial devices were no longer used to represent space in art, as modern painters reflected on the picture's essential flatness by reducing it to its basic elements - colour and form. However, during the 1960s, it was said that Performance, Object, and Conceptual Art, and the so-called "new media" had displaced painting. Richter and Polke, searching for their own approaches within this art world, contradicted this linear progress and continued to paint, despite widespread belief that the medium was "dead." In a revision of any style, genre, and pictorial form, they scrutinized traditional modes of representation and, as will be shown, unmasked their ideological implications.

\section{Dialectic}

In 1992, during his sccond Documenta exhibition, Richter presented a cabinet of wood panels. In this work he juxtaposed the 
Figure I. Sigmar Polke and Reiner Speck with the painting Blue Flower, 1992 (Photo: reproduced from Michael Juul Holm, ed., Sigmar Polke - Alchemist exh. cat., Louisiana Museum of Modern Art, 200I, 4I).

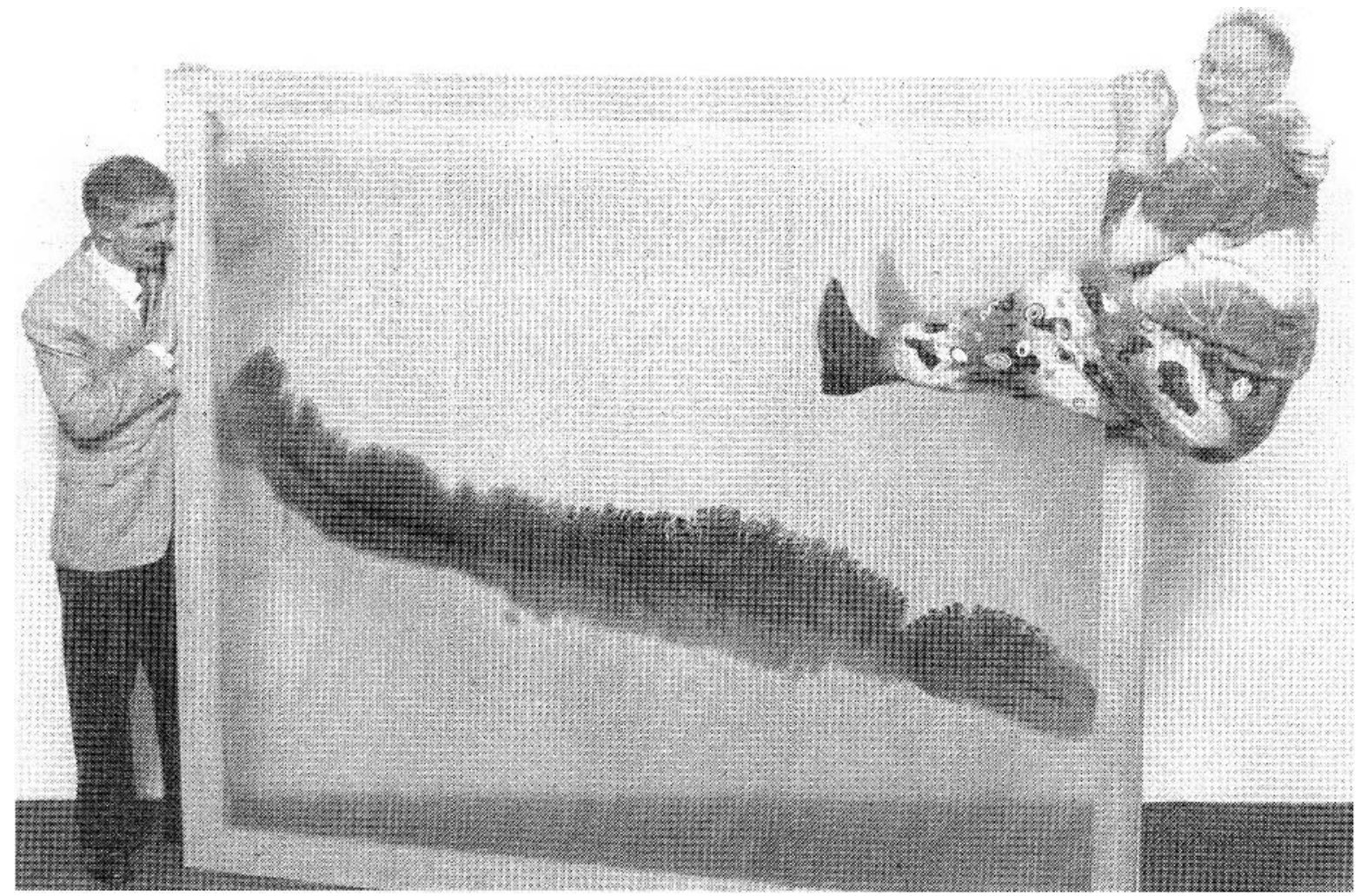

Figure 2. Gerhard Richter in his studio Fürstenwall, Düsseldorl, 1966. Photograph by Peter Dibke (Photo: reproduced from Hans-Ulrich Obrist, ed., Gerhard Richter. Text. Schriften und Interviews, Frankfurt am Main and Leipzig, 1993, 54).

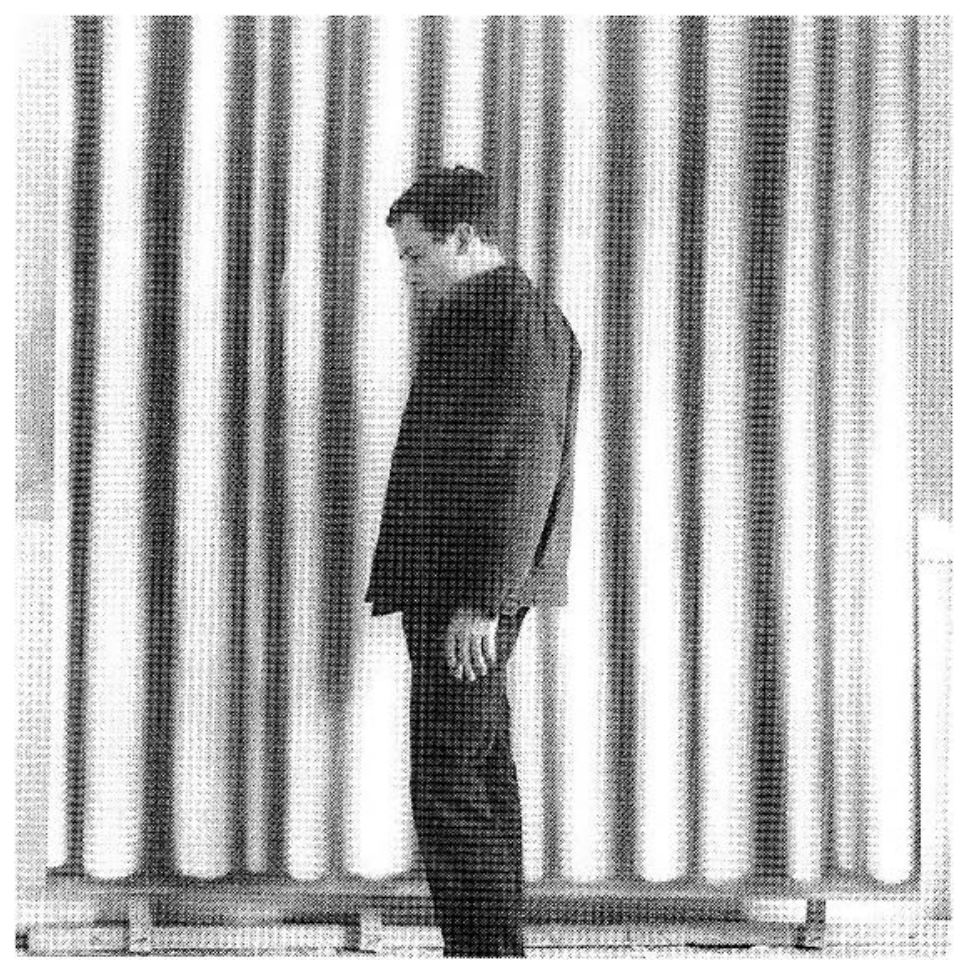

two contrary paradigms of pictorial representation by exploiting the duality between spatial illusionism and the naturally flat surface of the panels (fig. 3). Most of the pictures were abstract grey paintings with slight trails of colour. Richter also showed a grey mirror and a still life with flowers. This presentation of a single still life in the far right corner among thirteen abstract paintings requires closer examination (fig. 4). According to Clement Greenberg's famous essay "Modernist Painting" of 1960 , the grey paintings could still be described as modernistic reductions to the limitations inherent in the painting medium - "the flat surface, the shape of the support, the properties of the pigment." "Thus, Richter's grey paintings, at first glance, seem to take part in the "process by which pictorial art criticized and defined itself under Modernism" and oriented itself to flatness, "for flatness was the only condition painting shared with no other art." 8 Therefore, it is not surprising that the German press criticized Richter's somehow belated modernistic work at Documenta IX by complaining that it "remained flat."

In explaining why modernists called attention to painting's flatness, Greenberg stated that the "Old Masters" of realistic and naturalistic art had used the medium as a dissembling device, "using art to conceal art," as the 
Figure 3. Gerhard Richter, presentation of his cabinet at Documenta IX, 1992 (Photo: reproduced from Gerhard Richter, exh. cat., vol. II, Musée d'Art Moderne de la Ville de Paris, 1993, 66).

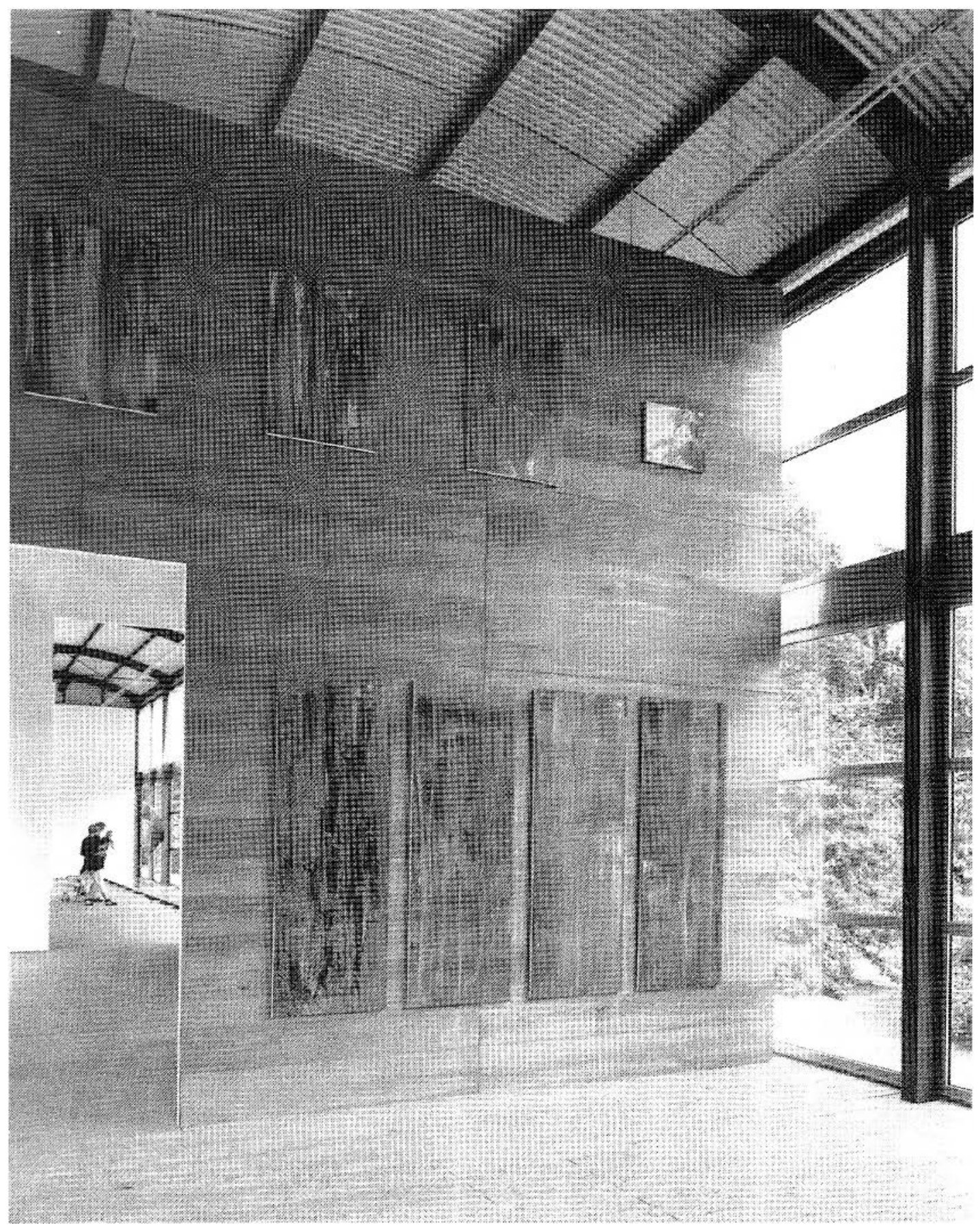

ancient topos says. ${ }^{10}$ Accordingly, the Old Masters had to avoid or resolve the contradiction between the enduring presence of flatness and their attempt to produce the most vivid illusion of three-dimensional space. One of the best examples for this artistic ambition is the genre of still life, in which the deceptive, illusory character seems to be as important as the subject itself. Pliny's writings describe the story of Zeuxis, the artist whose painting of a boy with grapes appeared so real that birds attempted to settle on the fruit. It was this historic tale that provided a reference for the fact that only pictures of immobile objects could have such eye-deceiving qualities. " As a result, Clement Greenberg's statement that one tends to see what is in an Old Master before onc sees the picture itself ${ }^{12}$ became particularly valid in regard to the still life. 
Figure 4. Gerhard Richter, Flowers, 1992. Oil on canvas, $41 \times 51 \mathrm{~cm}$. Private collection (Photo: reproduced in Robert Storr, ed., Gerhard Richter. Forty Years of Painting, exh. cat., New York, Museum of Modern Art, 2002).

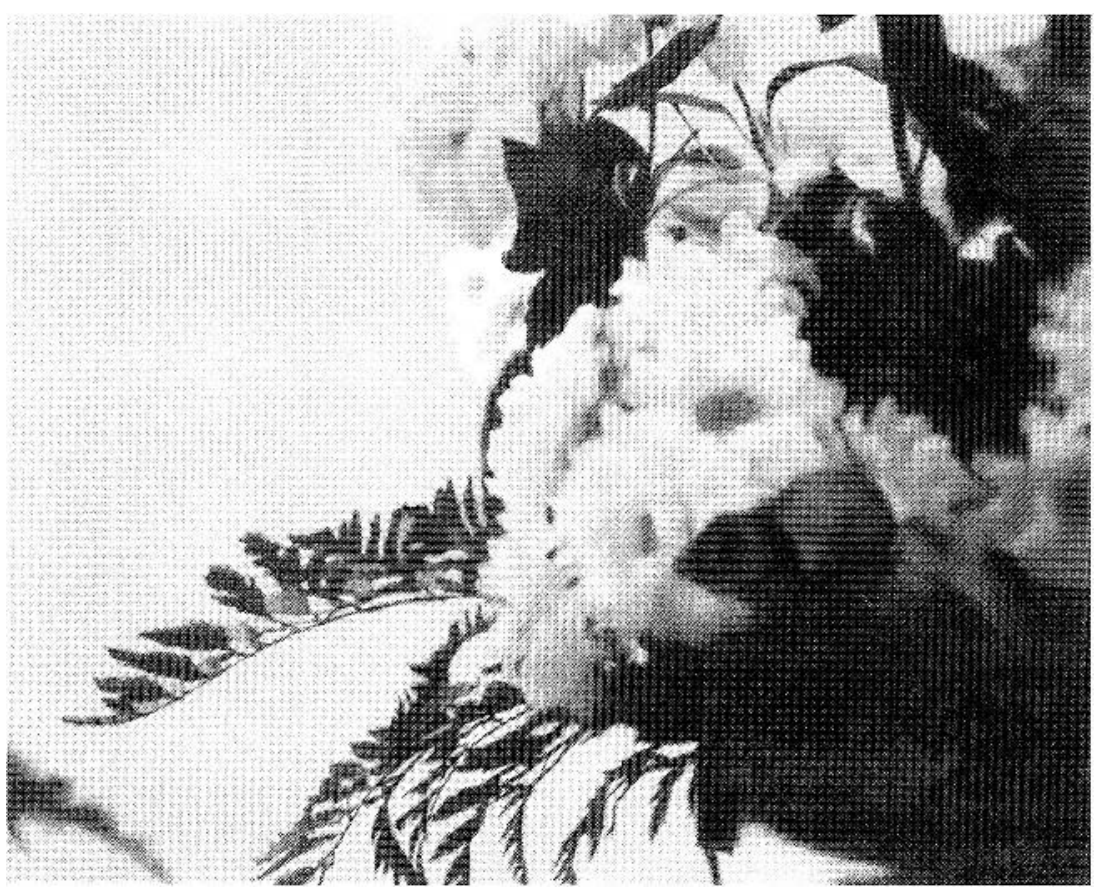

tension" between the picture's "transparency" and its "opacity." 14 By intensifying the so-called "iconic difference," 15 Richter alludes to the dialectic of traditional modes of representation that obviously cannot be overcome.

\section{Juxtaposition}

Sigmar Polke's statement of this dialectic appears much more playful than Richter's ambiguous and decorative presentation at Documenta IX. In works like This is how you sit correctly of 1982 (fig. 5), the traditional principles of representation are turned upside down. A furnishing fabric with an ornamental pattern of little dogs serves as the "canvas" and is partly covered with a grey, white, blue, and yellow colour-field painting. Over this field are drawn enlarged copies of engravings from disparate sources. These copies are combined and superimposed in fragments of different scales. While the women with chairs on their heads are borrowed from Goya's famous Caprichos series, the other motifs are derived from Max Ernst's Sur-

By presenting a still life among the grey paintings, Richter contrasted his abstract paintings with their polar opposite. What we see is the unresolved dialectic of the picture as a transparent window and, conversely, the picture as an opaque object and monochrome relief. The genre of still life proved to be a pcrfect reference for this investigation, as it had been shaped by this dialectic since the seventeenth century. On one hand, the still life dissembled the medium to achieve a perfect mimesis, while on the other it was characterized by a self-awareness that was expressed in meta-commentaries on its illusionism, as Victor Stoichita has shown. ${ }^{13}$

But a closer look at Richter's still life reveals that, in fact, his painting does not obey the traditional conventions of the genre: the bouquet in Richter's Flowers is not presented in a niche or on a table, as in most seventeenth-century paintings. Instead, we see only a detail of the bouquet, while the other half of the canvas consists of a white background that signals the picture plane. Furthermore, by slightly blurring the painting, Richter refers to the photograph he used as a model. Unlike the traditional full representation, we see a close-up in which depth is produced by different degrees of blurring. The blurred colour destroys the illusionism of the depicted flowers and emphasizes the opacity of the medium. It thus contradicts the idea of a transparent surface. At the same time, the reference to the indexical structure of the photograph produces a strong "iconic realist Novel in Collage: Une Semaine de bonté. ${ }^{16}$ The overlapping of disconnected narrative fragments and flat ornament inhibits the perception of space and produces a grotesque effect. One cannot distinguish between the depiction's foreground and background. The perspectival illusionism of the opened door does not lead into depth, as the flat colour fields cancel it out. Instead of repeating and confronting models of representation in individual paintings, like Richter, Polke juxtaposes pre-existing abstract, ornamental, and figurative forms in one picture. As a result, Polke neglects any polarization or hierarchy between the single modes of representation in order to exploit new devices of narration and representation.

Polke's work Measuring Clothes of 1994 (fig. 6) reveals that these narrations are usually presented ironically. For example, Abraham Bosse's treatise on perspective of 1647 includes the well-known illustration of three figures demonstrating the visual pyramid (the extrinsic rays that register the outlines of a geometrical form). ${ }^{17}$ In Iolke's work, copies of Bosse's diagrams are painted over actual garments that have been attached to the canvas. Polke's titlc suggests that the men are measuring the garments, but in reality the indicated correspondence between these different elements of the picture does not exist. The stripes and patterns of the garments contradict any illusion of depth and thus destroy the impression of perspective produced by the diagrammatic projections. By sewing ordinary garments onto 
Figure 5. Sigmar Polke, This is how you sit correctly (after Goya), 1982. Dispersion on fabric, $200 \times 180 \mathrm{~cm}$. Baden-Baden, Frieder Burda collection (Photo: reproduced from Sigmar Polke. Die drei Lügen der Malerei, exh. cat., Bonn, Kunst- und Ausstellungshalle der Bundesrepublik Deutschland, 1997).



the canvas and by projecting the noble figures onto them, Polke demonstrates that our vision is perhaps as superficial as a patterned cloth, since, according to post-modernist theory, perspective is also just a projection. Although Polke rejects traditional as wcll as modern modes of representation in this work, the polarization of these paradigms remains visible.
Synthesis

Unlike his juxtaposition of different abstract and figurative styles in This is How You Sit Correctly, Polke's application of halftone dots in various other works seems to overcome this polarization. If we look, for example, at his Rest on the Flight to Egypt 
Figure 6. Sigmar Polke, Measuring Clothes, 1994. Fabric and paint on canvas, $225 \times 300 \mathrm{~cm}$. Städtische Galerie Karlsruhe, Garnatz collection (Photo: reproduced from Sigmar Polke. Die drei lügen der Malerei, exh. cat., Bonn, Kunst- und Ausstellungshalle der Bundesrepublik Deutschland, 1997).



Figure 7. Sigmar Polke, Rest on the Flight to Egypt (after Hoogstraten), 1997. Plastic sealer on polyester fabric, $280 \times 350 \mathrm{~cm}$. Private collection.

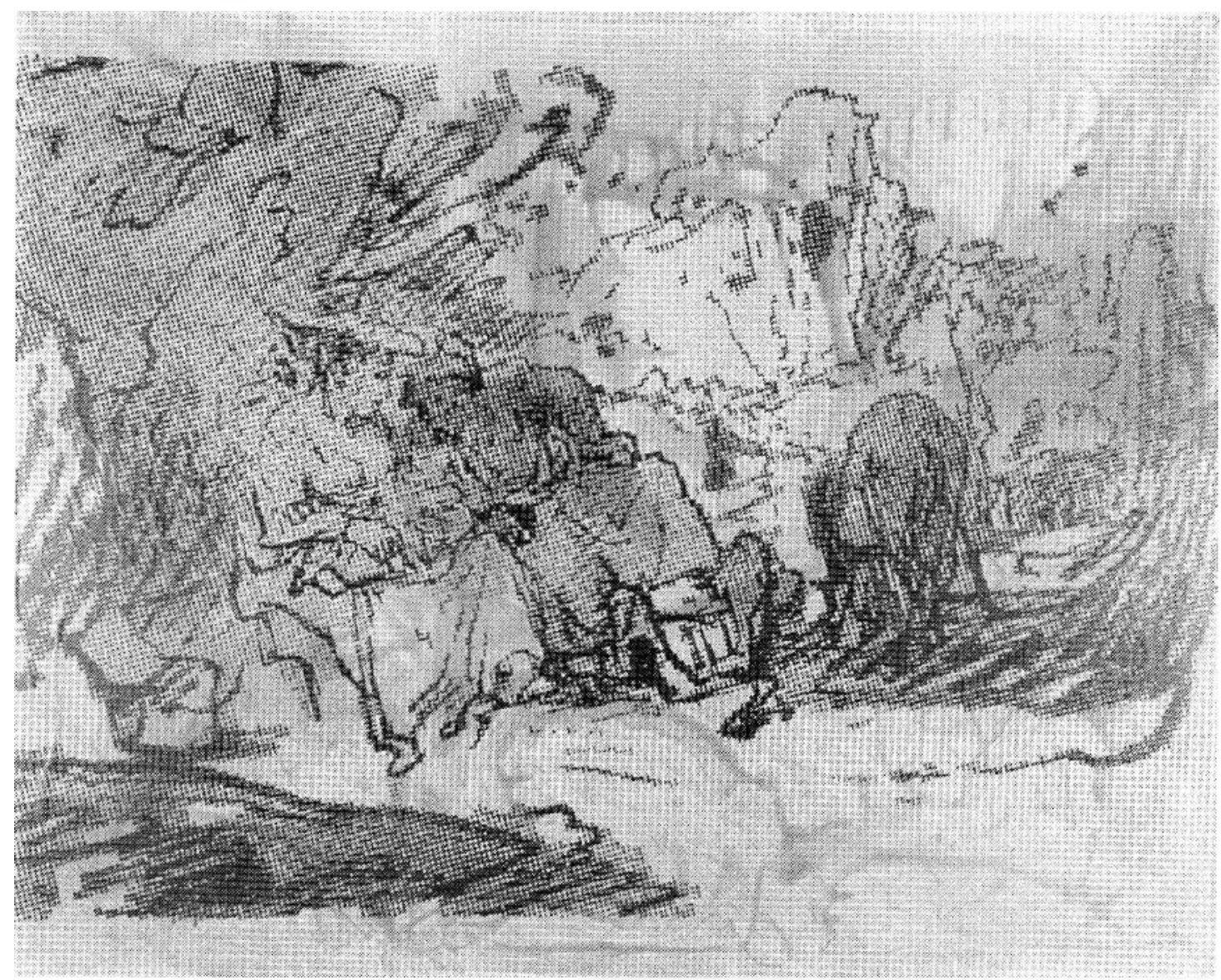


Figure 8. Gerhard Richter, Atlas, plate 252, 1971. Photographs in architectural sketches, $66.7 \times 51.7 \mathrm{~cm}$ (Photo: reproduced from Helmut Friedel and Ulrich Wilmes, eds, Gerhard Richter. Atlas der Fotos, Collagen und Skizzen, exh. cat., Munich, Lenbachhaus, 1998).
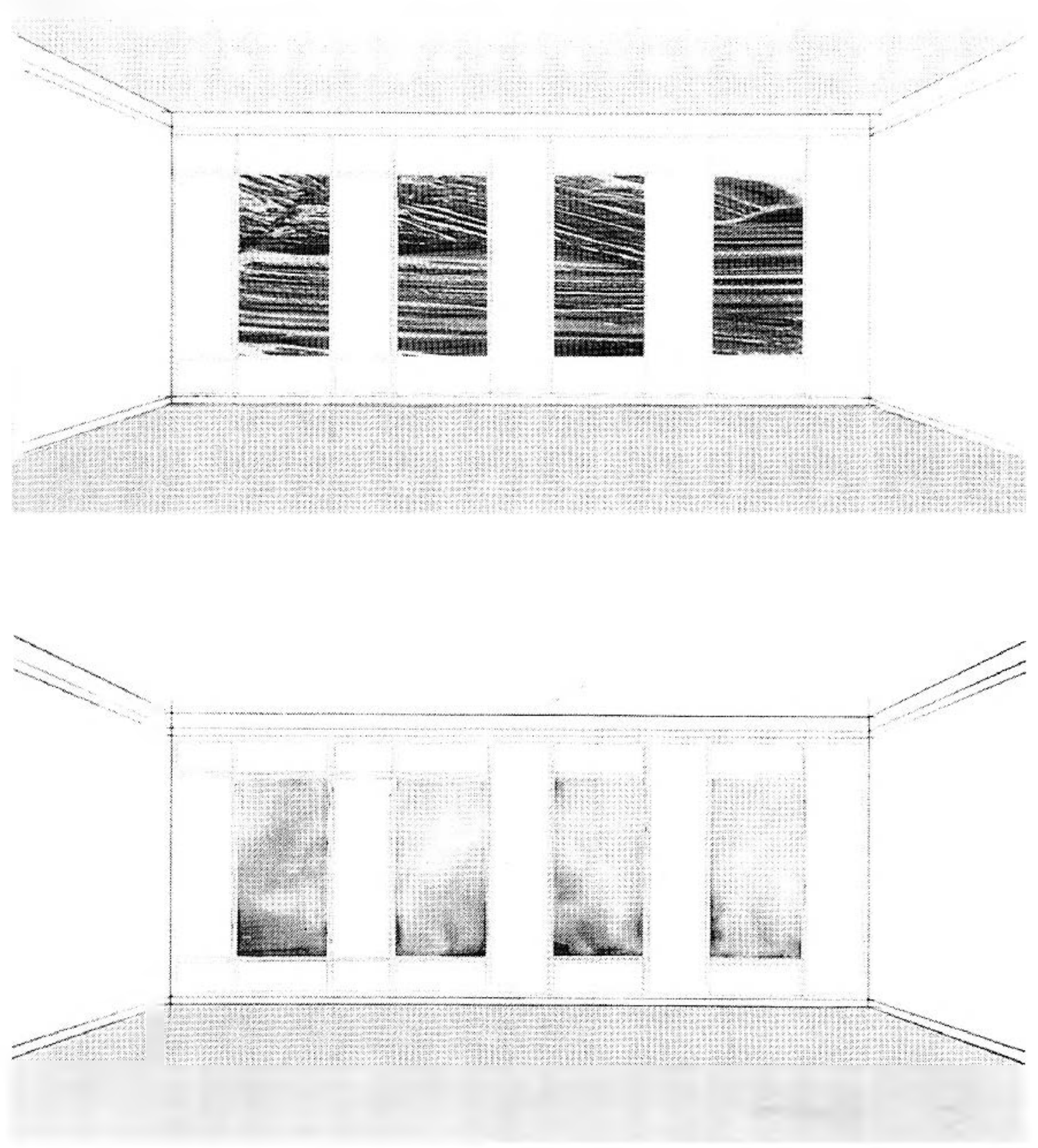

(after Van Hoogstraten) of 1997 (fig. 7), we can hardly recognize the subject. The mass of dots and imperfect spots, strategically placed by Polke, give the impression of an "all-over" structure well known from Jackson Pollock's informal abstraction. This impression is even intensified by the trails of plastic sealer on the polyester fabric. But apart from the random structure of these colours, when seen at a distance the arrangement of dots becomes readable and reveals an image of the Holy Family in a landscape. A drawing by Ferdinand Bol, formerly attributed to van Hoogstraten, was Polke's model for this image. The drawing, owned by the Museum Kunst Palast, Düsseldorf, likely attracted him because of the oil spots on its surface. Apart from this appropriation the painting, like most other dot paintings by Polke, can be seen as a paradoxical synthesis of flatness and space. As in a puzzle picture, we can see either the informal spots of colour or the figures in the landscape, but the two modes of representation cannot be separated from each orher since they are produced by the same pictorial elements. 
Figure 9. Gerhard Richter, Atlas, plate 250 (detail), 1971. Photographs in architectural sketches, $66.7 \times 51.7 \mathrm{~cm}$ (Photo: reproduced from Helmut Friedel and Ulrich Wilmes, eds, Gerhard Richter. Atlas der fotos, Collagen und Skizzen, exh. cat., Munich, Lenbachhaus, 1998).

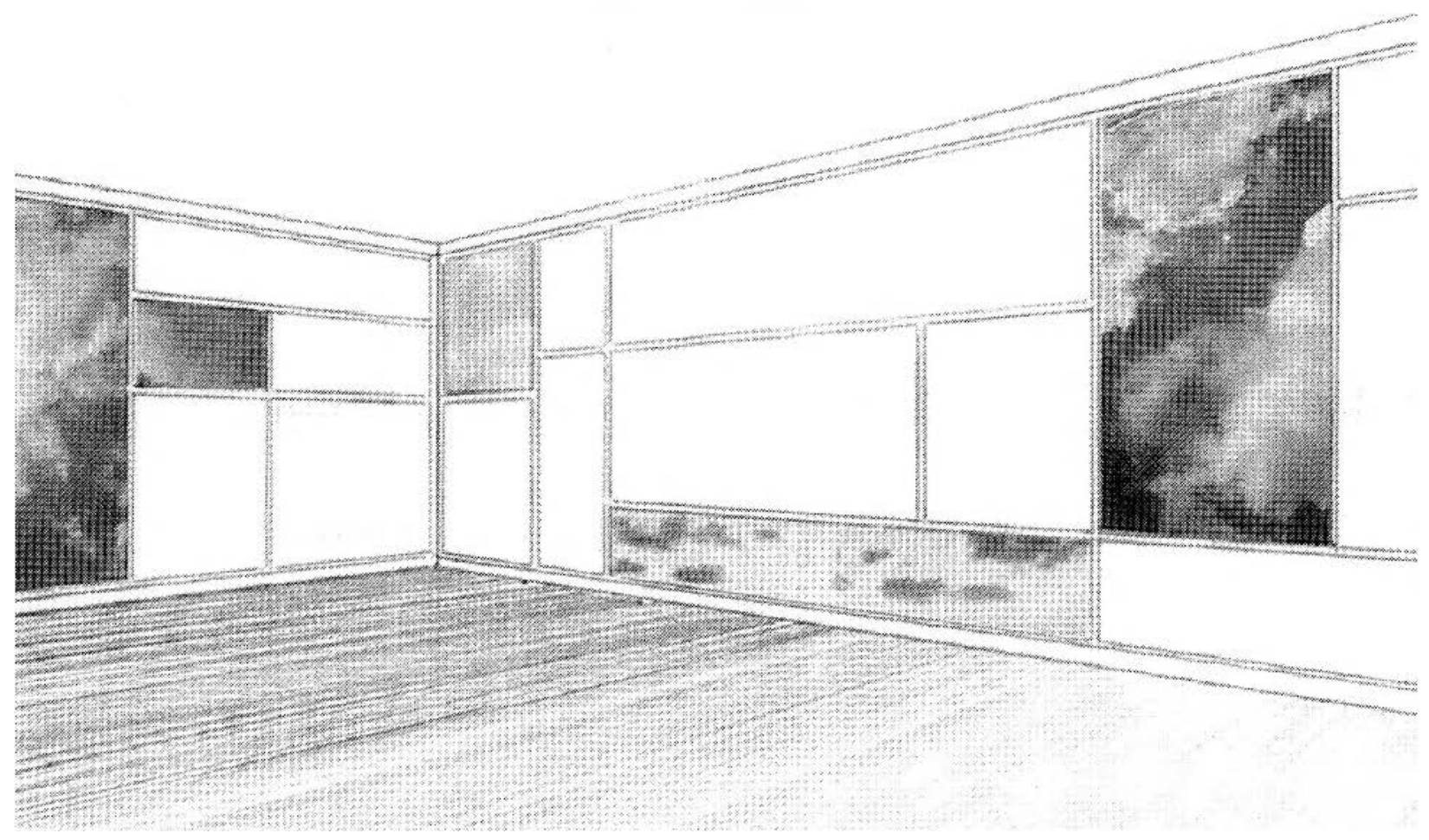

The same effect can be found in Richter's Townscapes and some of his landscapes in which blurred colours or violent brush strokes turn the naturalistic and photographic representation into an informal "all-over." Finally, the most conventional yet sophisticated example of such a synthesis of abstraction and mimesis is, of course, Curtain. Ever since Pliny's anecdote about Parrhasios and Zeuxis, the curtain has been the quintessence of trompe l'oeil. Its deceptive illusionism marks the boundary between the aesthetic space of the image and the space of the beholder, functioning as a repoussoir. In Richter's painting, as in Parrhasios's, the representation is restricted to this repoussoir, for the curtain does not conceal any illusory space behind it. Unlike the version in the photograph (fig. 2), a painting of $1965^{18}$ presents a curtain without its lower edge. In this version in particular, the textile alludes to Alberti's velum, the veil, ${ }^{19}$ which here has become opaque, since it is painted onto the support. As a result, the depiction on the canvas represents nothing but itself. Furthermore, the mimetic imitation of the textile's folds can be perceived as an abstract structure, as in Bridget Riley's painting Late Morning of 1967/68 (Tate Collection, London), in which Riley plays with the visual deception created by pure abstract forms. In our perception of Richter's painting, the folds alternate between mimetic and abstract forms, and take an intermediary position that overcomes the traditional polarization. It seems as if Richter wanted to demonstrate how one single mode of representation could serve different purposes. Furthermore, in the proximity of abstract and illusory forms, one may see an investigation of the visual effects of $O p$ Art.

Ideological Implications: Concepts of the Image - Concepts of Art History

Richter's decision to incorporate Curtain as a montage into one of his architectural designs of interior views, documented in Atlas, ${ }^{20}$ makes it clear that his painting does more than take up the post-war "Bilderstreit" between abstraction and figuration. Curtain also suggests a window view onto nature that Richter created in several other montages of images with clouds and landscapes. In these designs, the notion of the picture as a window is linked with the traditional function of windows as devices that separate an inner space from an outer space. The window-picture thus builds a frame for the perception of a distant landscape that seems to lie beyond the painting. ${ }^{21}$ But 
Figure 10. Sigmar Polke, Constructivist 1968. Dispersion on canvas, $150 \times 125 \mathrm{~cm}$. Munich, Bayrische Staatsgemäldesammlungen (Photo: reproduced from Sigmar Polke. Die drei Lügen der Malerei, exh. cat., Bonn, Kunst- und Ausstellungshalle der Bundesrepublik Deutschland, 1997).

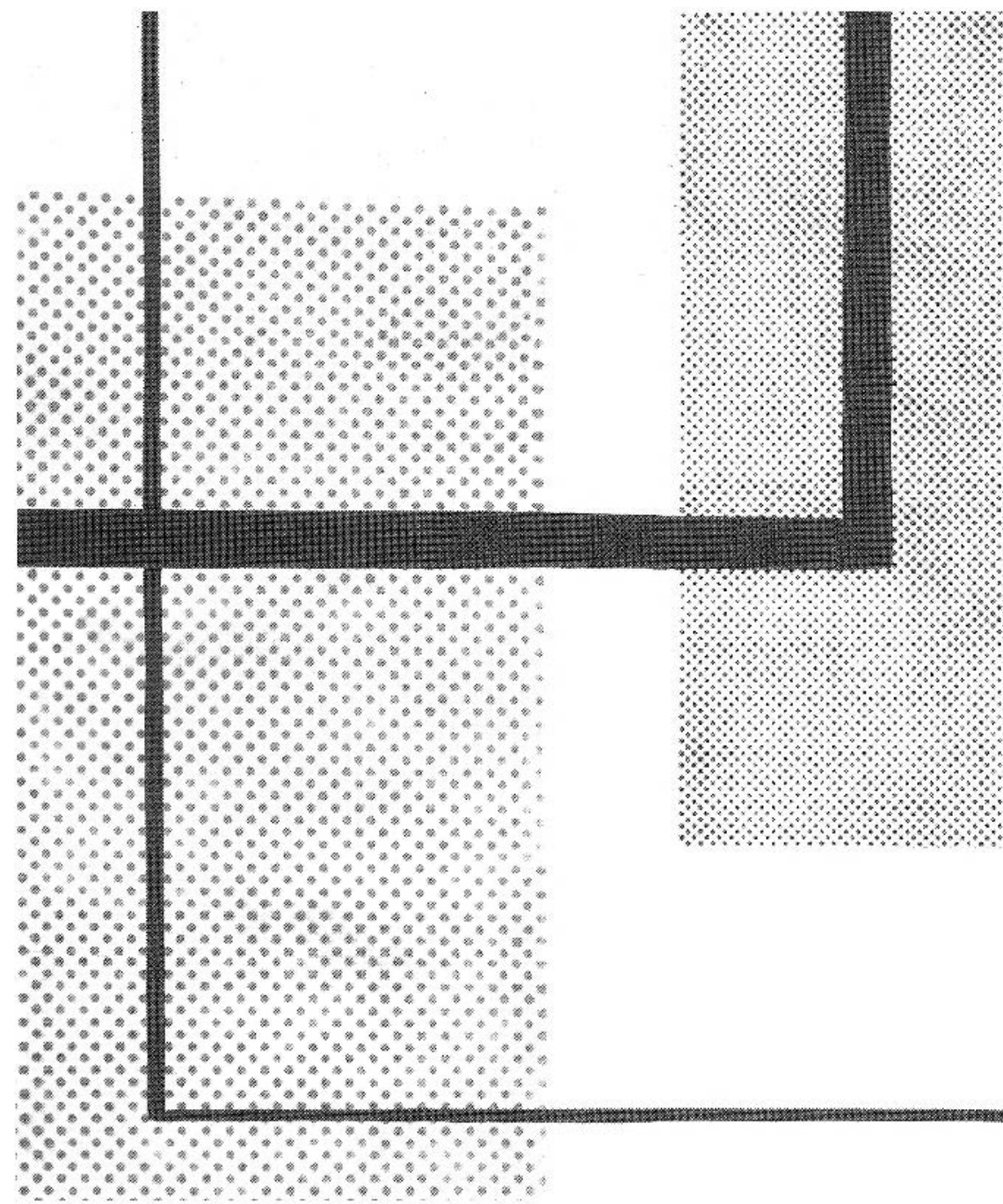

a response to modern architecture, such as Mies van der Rohe's New National Gallery in Berlin of 1962-68, others refer to NeoGothic altarpieces and thus, once again, suggest a connection between modernism and romanticism. In both cases, Richter's architectural fantasies can be understood as devotional spaces and can be connected to the modern myth of art as a refuge for religious fervour and as a secular form of belief.

If we look at plate 150 of Atlas (fig. 9), it becomes evident that this conncction between landscape and abstraction finds a parallel in the relation between window and grid. Robert Rosenblum defined Piet Mondrian's grid structure as a metaphorical reprise of the romantic window view and of the skeleton of thin rectilinear mullions. ${ }^{26}$ Rosalind Krauss further developed this notion in her fundamental study The Originality of the Avant-Ciarde in 1985, in which she defined the "grid" as the paradigm for modernists striving for originality. Krauss saw the origin of the modern grid in the window views of symbolist art, but she also stated that the grid clearly related back to the early nineteenth century and Romanticism. ${ }^{27}$ Richter's architectural design can be compared to Krauss's and Rosenblum's theoretical investigations. His montage of different cloud pictures in a grid structuring the walls of his imaginary room reveals that "nature" inspired the grid, although the latter persistently negates this foundation. Krauss de-

Richter's views into landscape allude above all to a romantic topos. ${ }^{22}$ In his architectural designs, as well as in his seemingly romantic landscapes and cloud paintings, the genre of landscape is presented as a category of the sublime. It is through this experience that landscape can also be connected with the process of abstraction. In some of the montages (fig. 8), the vicws of clouds or mountains appear interchangeable with abstract paintings. Consequently the landscapes are comparable to the "purc visuality" of monochrome surfaces. ${ }^{23}$ Richter, with artistic devices, seems to be reflecting a romantic tradition observed by Robert Rosenblum in 1975 - a tradition leading from the sacred landscapes of romanticism to transcendental abstraction and the abstract sublime. ${ }^{24}$ In addition, Richter reminds us that the idea of abstraction was pursued in the genre of landscape, as in Piet Mondrian's series of abstractions of trces or of the seaside. ${ }^{25}$ While some of the architecrural designs in Atlas appear as scribed the grid's aversion to nature as "protectiveness of its mesh against all intrusions from outside ... - for the grid has collapsed the spatiality of nature." 28 Now, Richter's combination of a grid and clouds recalls this "collapsed spatiality of nature"; the "antinatural, anti-mimetic and anti-real" ${ }^{29}$ grid cannor, in fact, abandon its function as a window and its illusory and fictional implications. In this sense, as Krauss also pointed out, "The grid's mystic power is that it makes us able to think we are dealing with materialism ... while at the same time it provides us with a release into belief (or illusion, or fiction)." 30

This same connection of the supposed-anti-natural grid and its function as a window is maintaincd by Polke's translucent paintings that reveal the support structure of the wooden stretcher. Through this visual play, Polke's art links both concepts and, at the same time, demonstrates their absurdity (fig. 1). What Krauss defines as anti-natural, anti-mimetic, and 
Figure 11. Sigmar Polke, Seeing things as they are, 1992. Artificial sealant and artificial resin on polyester fabric, $300 \times 225 \mathrm{~cm}$. Karlsruhe, Städtische Galerie, Garnatz Collection (Photo: reproduced from Sigmar Polke. Die drei Lügen der Malerei, exh. cat., Bonn, Kunst- und Ausstellungshalle der Bundesrepublik Deutschland, 1997).

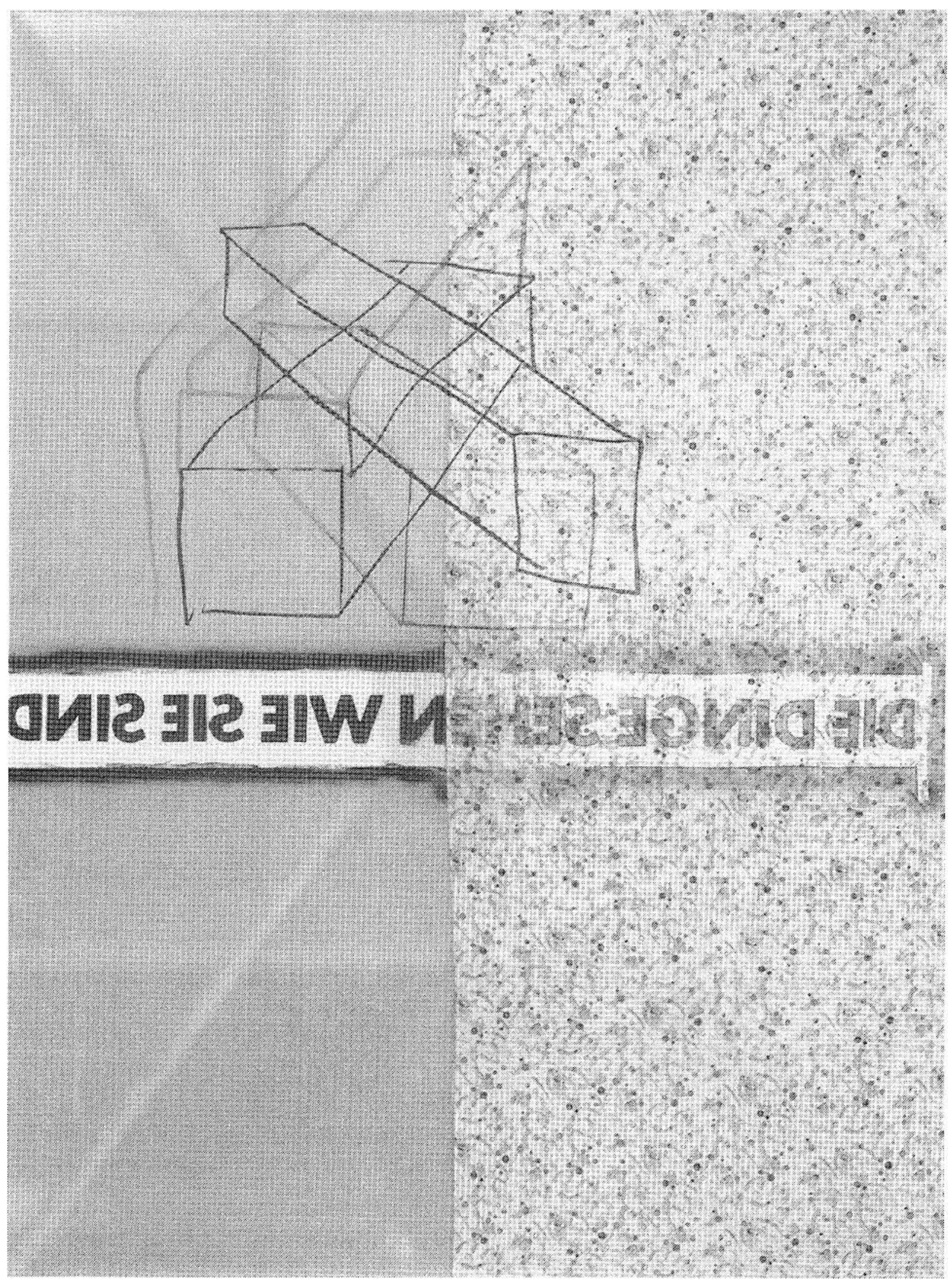


Figure 12. Sigmar Polke, History of Everything II, 2002. Mixed media on fabric, $403 \times 303 \mathrm{~cm}$. Courtesy Michael Werner Gallery, New York and Cologne (Photo: reproduced from John R. Lane and Charles Wylie, eds, Sigmar Polke. History of Everything. Paintings and Drawings 1998-2003, exh. cat., Dallas, Museum of Art, 2003).
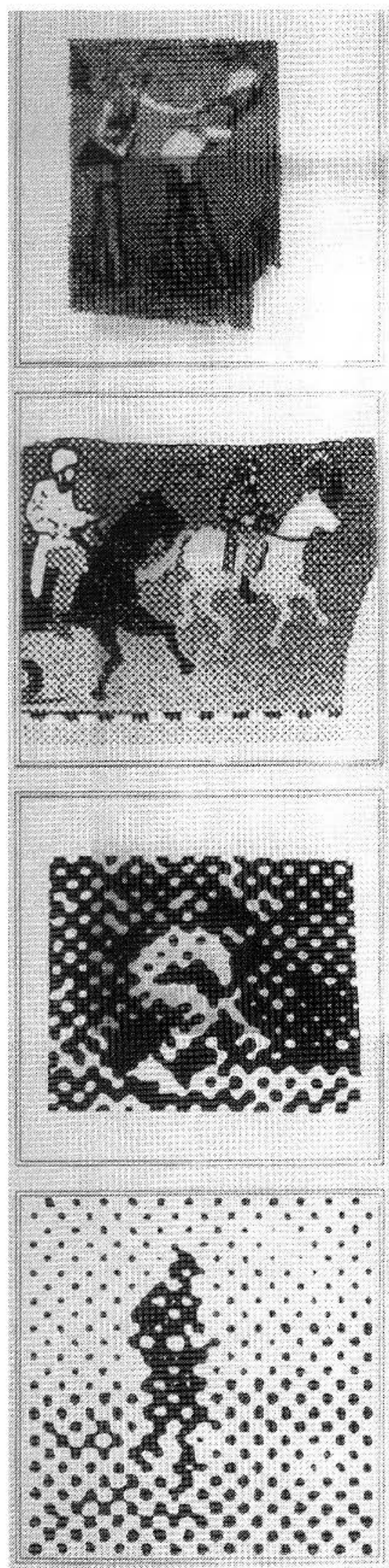
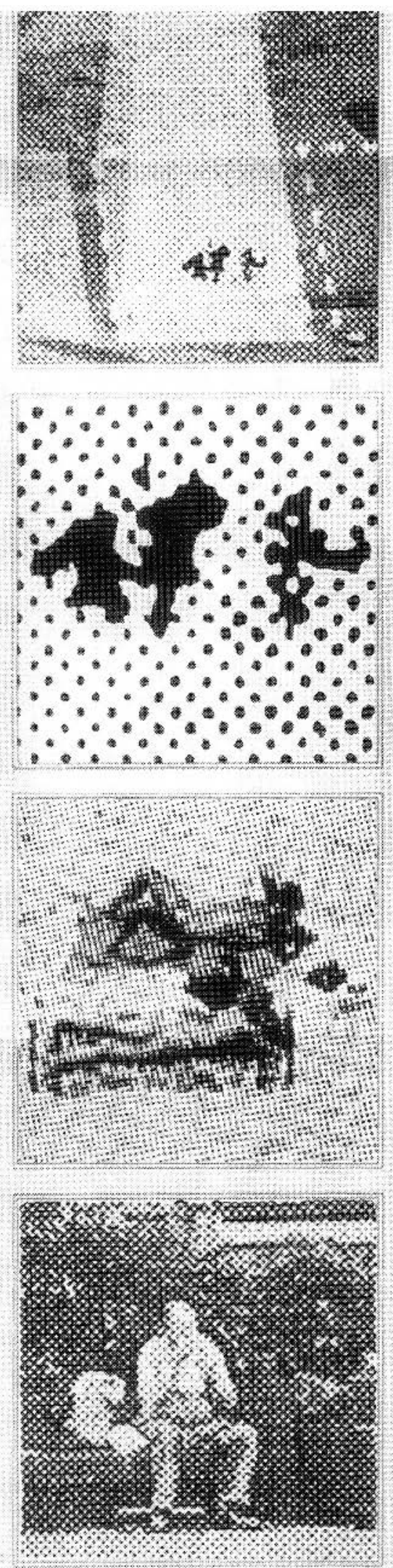
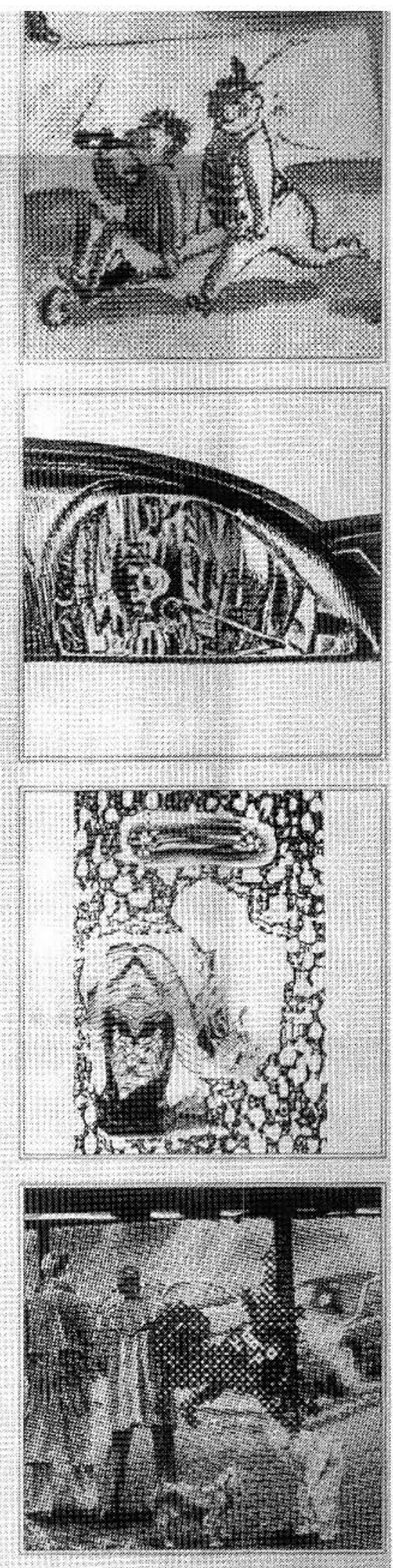
Figure 13. Sigmar Polke, War and/or Peace, 2002. Machine painting on fabric, $366 \times 954 \mathrm{~cm}$ (Photo: reproduced from John R. Lane and Charles Wylie, eds, Sigmar Polke. History of Everything. Paintings and Drawings 1998-2003, exh. cat., Dallas, Museum of Art, 2003).

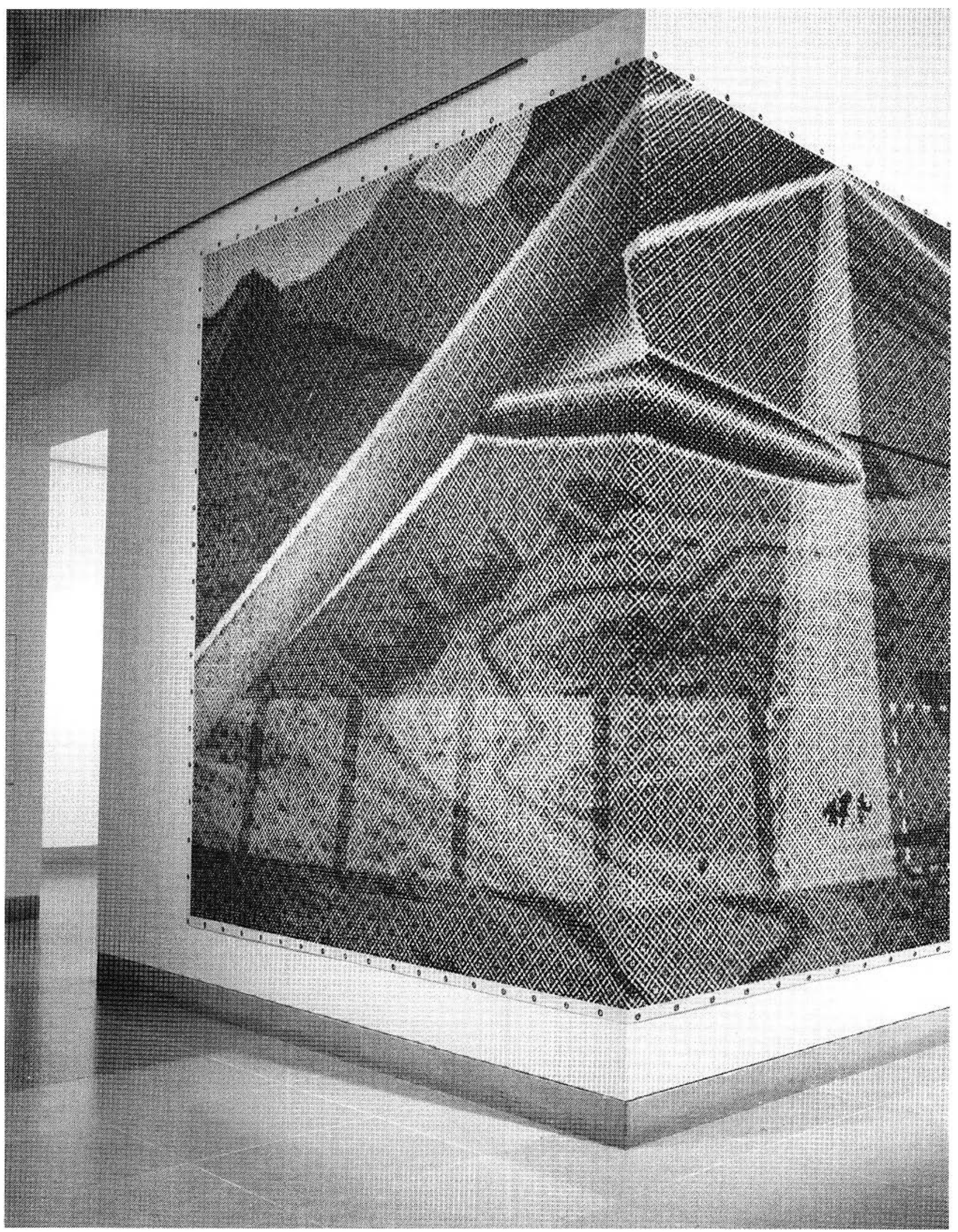


anti-real, is, in Polke's work, impertinently subverted through slight manipulations of the reperitive geometrical structure. For instance, his painting Constructivist of 1963 (fig. 10) is an almost malicious demonstration of a grid transformed into mimetic forms with a precise significance. Polke has converted the rectangular grid into a fragment of a swastika and thus illuminates the strong ideological implications inherent in every form or style. By perverting modernist abstraction with allusions to the mimetic tradition, Polke, to an even greater extent than Richter, insists on the symbolic meaning of every form of representation, whether it is two- or three-dimensional.

\section{Seeing Things as They Are? Comments on Visual Culture}

Richter's Four Panes of Glass of 1967, in the Herbert collection in Ghent, was revolutionary, as it allowed viewers to control how they perceived the work. Offering only four frames filled with glass that could be turned on its axis by the spectator, Richter reduces the grid to its essential components and does not create an illusory space beyond the frame. Four Panes of Glass provides only the basic conditions for the perception of an image. It is up to the spectator to create a view by turning the panels and choosing the detail. In the same way, Richter's installation Eight Grey of 2002, in the Deutsche Guggenheim in Berlin, abstains from representation by presenting only grey "foils" that project an image of the viewer. By reflecting the exhibition space in this monumental work of slightly angled sheets of glass, the illusionistic space that is created becomes site-specific. Richter leaves it up to the spectator to decide whether the eight sheets of glass are pure surfaces, "things," or reflections of an architectural and social space. The lack of images and commentary paradoxically uncovers every myth of representation while simultaneously reinstating them. Thus, the work demands that the observer account for what can be seen.

Seeing Things as They Are from 1992 (fig. 11) is another work by Polke that ironically demonstrates that things can never be seen as they are. We read the sentence in reverse and are invited to look behind words and objects. Through this process, Polke confirms that the image is something multifaceted, insubstantial, and instable. Works he showed in Dallas and London from 2002 to 2004, in an exhibition titled History of Everything, convey the same message. In these paintings, derived from newspaper images about America's internal and external politics, Polke seems to be investigating a collective visual culture. His subjects were mainly influenced by Texas newspapers, but in his title, History of Everything, he claims to give a general view of our time. In the two paintings History of Everything $I$ and History of Everything $I I$ the artist charts in an indexical way how images are made: one grid features abstract dot patterns that we see only as holes or voids, while its figurative opposite (fig. 12) makes readable different images of ordinary subjects. These pictures seem to indicate the general question of the show: "How can our vision of historical events be represented?" Another painting in the exhibition, a newsprint-derived banner titled The Hunt for the Taliban and Al Qaeda, provided its readers with graphic explanations of the aerial surveillance technology used by American forces in the Middle East. Its companion piece, War andlor Peace, is a machineprinted painting showing a detail from The Hunt for the Taliban and Al Qaeda, which Polke wrapped around a corner of the room, thereby bending the image, skewing its orientation, and removing it from its original context (fig. 13). As art critic Dave Hickey comments in the exhibition catalogue,

\begin{abstract}
The photographic eyes of the flyers gaze down from their superior heights and see (it seems) whatever they wish to see, and wc, museum-goers, gazing at enlarged versions of these images, also see what we wish to see. In this parable of social distances, the pilots of the surveillance aircraft looking down from extreme elevation cannot distinguish friend from foe, and the muscum visitor looking at the enlarged image from too close a range is equally at a loss to distinguish a horseman from a blob of ink. ${ }^{31}$
\end{abstract}

In these paintings, the representation of historical events no longer seems to be a question of space or non-space, of perspective or depth. Polke's inference here is that the world of images and its ideological production of historical "facts" is accessible only from the proper social distance. ${ }^{32}$

Notes

1 For the contest of Parrhasios and Zeuxis, see Pliny, Natural History IX (Libro XXXV) (London and Cambridge, Mass., 1962), 30811.

2 Oskar Bätschmann and Christoph Schäublin, eds, Leon Battista Alberti, De Statua, De Pictura, Elementa Picturae/Das Standbild, Die Malkunst, Grundlagen der Malerei (Darmstadt, 2000), 22425; Leon Battista Alberti, On Painting, ed. Martin Kcmp, trans. Cecil Grayson (London, 1991), 54.

3 For Richter's and Polke's friendship and comperition, see Hubertus Butin, "Gerhard Richter und Sigmar Polke - eine Künstlerfreundschaft als mikrosoziales System," Legitimationen. Künstlerinnen und Künstler als Autoritäten der Gegenwartskunst, ed. Julia Gelshorn (Bern, Frankfurt, and New York, 2004), 43-59; Dietmar Elger, Gerhard Richter, Maler (Cologne, 2002), 230.

4 Jost Hermand, "Die restaurierte 'Moderne'. Zum Problem des Stilwandels in der bildenden Kunst der Bundesrepublik Deurschland um 1950," Stil und Gesellschaft. Fin Problemaufriss, Fundus-Bücher LXXXIX/XC, ed. Friedrich Möbius (Dresden, 1984), 279-302. Laszlo Glozer, ed., Westkunst. Zeitgenössische Kunst seit 1939, exh. 
cat., Cologne, Museen der Stadt Köln (Cologne, 1981), 172-211. Bernd Growe, "Bilderstreit um die Moderne. Zur deutschen Kunstkritik der Nachkriegszeit," 1945-1985. Kunst in der Bundesrepublik Deutschland, ed. Dieter Honisch, exh. cat., Berlin, Nationalgalerie Staatliche Museen Preussischer Kulturbesitz (Berlin, 1985), 673-82. Martin Warnke, "Von der Gegenständlichkeit und der Ausbreitung der Abstrakten," Die fünfziger Jahre. Beiträge zu Politik und Kultur, Deutsche TextBibliorhek V, ed. Dieter Bänsch (Tübingen, 1985), 209-22. Ulrikc Wollenhaupt-Schmidt, documenta 1955. Eine Ausstellung im Spannungsfeld der Auseinandersetzungen um die Kunst der Avantgarde 1945-1960, Europäische Hochschulschriften XXVIII/CCXIX (Frankfurt am Main, Berlin, and Bern, 1994).

5 Werner Haftmann, "Malerei nach 1945," II. documenta '59. Kunst nach 1945, exh. cat., Kassel, Museum Fridericianum, Orangerie und Bellevue-Schloss (Cologne, 1959), vol. I, 11-19, esp. 12-14; Clement Greenberg, "Modernist Painting" [1960], Modernism with a Vengeance 1957-1969, vol. IV, Clement Greenberg. The Collected Essays and Criticism, ed. John O'Brian (Chicago and London, 1993), 85-106.

6 Haftmann, "Malerei nach 1945," 14. Peter J. Schneemann, "Entwürfe der Abstraktion. Begriffe, Geschichten und Werte," Kunst und Architektur in der Schweiz 2 (2001), 6-11. For the French situation, cf. Harriet Weber-Schäfer, Die Kontroverse um Abstraktion und Figuration in der französischen Malerei nach 1945 (Cologne, 1997).

7 Greenberg, "Modernist Painting," esp. 86.

8 Greenberg, "Modernist Painting," 87.

9 Wolf Schön, "Nabelschau des Himmelsstürmers," Rheinischer Merkur, 19 June 1992, 33.

10 Greenbcrg, "Modernist Painting," 86.

11 Plinius, Naturalis historiae.

12 Greenberg, "Modernist Painting," 87

13 Victor I. Stoichita, L'instauration du tableau. Métapeinture à l'aube des Temps modernes (Paris, 1993).

14 For the "iconic tension" between "transparency" and "opacity," see Gottfried Boehm, "Die Wiederkehr der Bilder," Was ist ein Bild?, eds Gottfricd Boehm and Helmut Pfotenhauer (Munich, 1994), 11-38, esp. 35. Arthur C. Danto, The Transfiguration of the Commonplace. A Philosophy of Art (Cambridge, Mass. 1981), 156-64. Philippe Junod, Transparence et opacité. Essai sur les fondements de l'art moderne (Lausanne, 1976).

15 For the notion "iconic difference," see Gottfried Boehm, "Was heisst: Interpretation?" Kunstgeschichte - aber wie? Zehn Themen und Beispiele, eds Clemens Fruh, Raphael Rosenberg, and HansPeter Rosinski (Berlin, 1989), 13-26, esp. 17-19; Boehm "Die Wiederkehr der Bilder," 29-36; Axel Müller, Die ikonische Differenz. Das Kunstwerk als Augenblick (Munich, 1997).
16 Gabriele Wix, "Of Snakes, Sleeping Mothers, and Butterflies without Wings. Polke reads Ernst," in Parkett 30 (December 1991), 105-08.

17 Abraham Bosse, Manière universelle de M. Desargues pour pratiquer la perspective par petit pied, comme le géométral, Ensemble des places et proportions des fortes et faibles touches, teintes ou couleurs (Paris, 1647-48). See also Martin Kemp, The science of art. Optical themes in western art from Brunelleschi to Seurat (New Haven and London, 1990).

18 Gerhard Richter, Vorhang II, 1965, oil on canvas, $200 \times 195 \mathrm{~cm}$, Berlin, Staatliche Museen Preussischer Kulturbesitz, Nationalgalerie.

19 Alberti: On Painting, 65-67; see also the introduction of Oskar Bätschmann in Bätschmann/Schäublin, Leon Battista Alberti, 6972.

20 Gerhard Richter. Atlas der Fotos, Collagen und Skizzen, eds Helmut Friedel and Ulrich Wilmes, exh. cat., Munich, Lenbachhaus (Cologne, 1997), figs. 218-54; the curtain fit into the architectural setting is to be found in fig. 248.

21 For the window as view into landscape, see Stoichita, L'instauration, 51.

22 See Lorenz Eitner, "The Open Window and the Storm-Tossed Boat: an Essay in the Iconography of Romanticism," The Art Bulletin XXXVII (December 1955), 281-90. J.A. Schmoll (gen. Eisenwerth), "Fensterbilder. Motivketten in der europ. Malerei," Beiträge zur Motivkunde des 19. Jahrhunderts, Studien zur Kunst des 19. Jahrhunderts VI, 1970, 13-165.

23 For the topos of "purity," see Greenberg, "Modernist Painting," 86. See also Mark A. Cheetham, The Rhetoric of Purity. Essentialist Theory and the Advent of Abstract Painting (Cambridge, Mass., 1991).

24 Robert Rosenblum, Modern Painting and the Northern Romantic Tradition (London, 1975).

25 See Regine Prange, "Das ironische Gesamtkunstwerk. Zur Richter-Retrospektive in der Kunst- und Ausstellungshalle der Bundesrepublik Deurschland, Bonn, 10. Dezember 1993-13. Februar 1994," Kunstchronik 47, 9 (1994), 563-79, esp. 572.

26 Rosenblum, Modern Painting, 174.

27 Rosalind Krauss, The Originality of the Avant-Garde and Other Modernist Myths (Cambridge, Mass., and London, 1985), 16.

28 Krauss, The Originality, 158.

29 Krauss, The Originality, 9.

30 Krauss, The Originality, 12.

31 Dave Hickey, "Sigmar Polke's Appointment in Texas," Sigmar Polke. History of Everything. Paintings and Drawings 1998-2003, eds John R. Lane and Charles Wylie, exh. cat., Dallas Museum of Art; London, Tate Modern (Dallas, 2003), 22-31, esp. 27.

32 Hickey, "Sigmar Polke's Appointment," 27. 